\title{
ШУМЕН ПО ВРЕМЕ НА ВТОРАТА СВЕТОВНА ВОЙНА
}

\author{
Бисер Георгиев \\ SHUMEN DURING THE SECOND WORLD WAR \\ Biser Georgiev
}

\begin{abstract}
This article traces the development of the city of Shumen and partly of the Shumen region during the Second World War. Some important issues of the political, economic and cultural development of the city and the region are discussed. Emphasis is placed on the prosperity of the city of Shumen, which is mainly due to the fact that many of the senior representatives of the executive power were born in this city.
\end{abstract}

Keywords: Shumen, World War II, Bulgaria, Shumen region.

DOI: https://doi.org/10.46687/SZVF4178

Началото на Втората световна война променя световната история из основи. За по-малко от година огромна част от планетата и почти цяла Европа е обхваната от пламъците на войната. При това до този момент светът не е виждал касапница в толкова големи размери. Изменя се всичко. Като се започне от елементарния бит и се стигне до психиката на хората. След тази война нищо вече не е същото. Технологиите се развиват с бесни темпове главно в областта на военното дело. След войната жените почти навсякъде получават равни права с мъжете. Светът започва да говори за комунизъм и се установят две взаимно противоречащи си системи, които се надпреварват във всички области и се опитват да завоюват аудитория в целия свят. Но скромната есен на 1939 г. е само началото на прелома. По това време в Шумен животьт тече с присъщите до този момент бавни темпове. Привидно всичко е спокойно. От 9 до 16 септември с. г. се провежда традиционният Шуменски панаир, но успоредно с него започват промени в местната администрация. Още в началото на септември старият областен директор е заменен с нов Стефан Пенев. Същият е шуменец и обществеността очаква да се грижи за интересите на областта ${ }^{1}$.

1 септември 1939 г. заварва на власт кмета Н. Райчев, но времето му изтича. Почти успоредно с оповестяването на новите парламентарни

\footnotetext{
${ }^{1}$ Shumenska zarya № 110/ 09.09.1939.
} 


\section{Бисер Георгиев. Шумен по време на...}

избори ${ }^{2}$, на които в Шуменска област кандидатстват едва 167 души за 27 депутатски места, е обявено неговото уволнение ${ }^{3}$. Според някои автори (Haralanova, Rumenov 2002: 59) освобождаването на Стойчев става на 5. XII. 1939 г., което не е от съществено значение. Ниската избирателна активност е лесно обяснима, като се има предвид силно усложнената процедура по изборите, необходимостта кандидатите да бъдат предварително утвърждавани по сложна, измислена от властта система и пр. Независимо от това прави впечатление, че пресата ратува за избирането на „специалисти и практици”, което далеч не е присъщо за демократичните нагласи на шуменци. Примирението, което се забелязва при създалата се обстановка, почти няма аналог в предходната история на града.

В началото на декември 1939 г. Райчев е наследен на кметския пост от инж. Христо Тонев. Последният е един от видните граждани на Шумен, оказали влияние върху развитието на града от края на Първата до средата на Втората световна война. Роден е през 1891 г. Следва в Лозана, но впоследствие се премества в „Политехниката” в Берлин, където завършва Инженерно-строителния и водопроводен факултет. Взема участие и в двете световни войни. През Първата достига чин капитан от запаса. След нея е началник на Водоснабдителното бюро при Шуменската окръжна постоянна комисия. Около 10 години по-късно е началник на Техническата служба при Шуменската община. Всичко това сочи, че познава добре проблемите на града. Тонев не за първи път е кандидат за кметското място. Името му се спряга още през 1938 г., но по някаква причина тогава не е предпочетен. Вероятно заради това заминава на работа в Пловдив. Заемането на поста през зимата на 1939 г. прилича на триумфално завръщане, но иначе добрият инженер се задържа на кметското място по-малко от 3 месеца - до 20. II. 1940 г., след което е назначен като Главен директор на благоустройството.

Като постоянен сътрудник на вестник „Шуменски глас"4 Хр. Тонев има позитивно отношение към пресата. Затова като кмет той става създател на вестник „Шуменски общински вести”, чийто първи брой

\footnotetext{
2 Конкретният повод за разпускането на Двадесет и четвъртото обикновено народно събрание е едно посещение на неговия председател Ст. Мошанов в Лондон през лятото на 1939 г. То предизвиква остра реакция в Берлин и под натиска на монарха събранието отива в историята (Todorov 2018: 459 и цит. лит.).

${ }^{3}$ Shumenska zarya, No 121/ 25.11.1939.

${ }^{4}$ Shumenski glas, № 1058/ 9.12.1939.
} 


\section{Годишник на ФХH, XXXII A}

излиза през януари 1940 г. $^{5}$ по време на неговия мандат. Тонев е и първият кмет, който се интересува от постигнатото от своите предходници, опитвайки се да създаде летописна книга за тях (Haralanova, Rumenov 2002: 61).

Още вестта за появата на „Шуменски общински вести” настройва частната преса в Шумен негативно по отношение на новото издание. Признавайки, че като областен центьр Шумен заслужава да има свой вестник по подобие на Варна и София, вестник „Шуменска заря” веднага прави уговорката, че общините в останалите областни центрове не конкурират частната преса и дори пускат обявите си в частните издания, а не в нея. Нещо, което шуменското общинско издание не прави. Нещо повече: частните вестници се чувстват застрашени от факта, че общинският вестник се опитва да ги заличи. С известно основание те сочат и безсмислеността на една публикувана в бр. 2 на общинското издание статия относно спекулата с дървата за огрев. Изводът, че ако кметът има точна информация за това, следва да затвори престьпника, а не да пише по вестниците, в случая е основателен ${ }^{6}$.

Парламентарните избори, проведени през февруари 1940 г., излъчват двама депутати от Шумен - Марин Иванов Тютюнджиев и Симеон Симеонов ${ }^{7}$.

Новата обстановка в Европа след 1. IX. 1939 г. налага промени и в България. Утвърждаването на Георги Кьосеиванов на власт, клонящ към възстановяване на партийно-политическия живот, явно не е по вкуса на Борис III и още на 16 февруари той го заменя с проф. Богдан Филов учен с голяма известност, дотогава министър на просветата, но с подесни политически възгледи (Dimitrov 1969: 27). В новия кабинет Иван Багрянов остава министьр на земеделието и държавните имоти, но влиза още един шуменец - инж. Димитьр Василев, като министьр на обществените сгради, пътищата и благоустройството (Balgarskite darzhavni institutsii 1986: 326).

Промяната на върха засяга и общинската власт. Четири дни след встъпването на новото правителство в длъжност, на 20 февруари 1940 г.,

\footnotetext{
${ }^{5}$ Shumenski obshtinski vesti, № 1/ 15.01.1940 г. Версията, че вестникът започва да излиза през февруари (Haralanova, Rumenov 2002: 61), най-вероятно е техническа грешка на авторите, каквито изобилстват в посоченото издание.

${ }^{6}$ Shumenska zarya, № 127/ 25.01.1940.

7 Д. Игнатовски (Ignatovski 2005: 145) допуска техническа грешка, сочейки името на втория депутат като Стоимен Стоименов.
} 


\section{Бисер Георгиев. Шумен по време на...}

Тонев е уволнен, а на 1 март на неговото място е назначен Христо Хараламбиев с помощник-кмет Никола Шамарджиев, който явно се оказва изключително подходящ за заеманата при няколко различни общински управници длъжност. Секретар на общината става Д. Пастармаджиев. На мястото на поста околийски управител на Шумен, заеман от Хараламбиев, е назначен шуменецът Васил Н. Василев дотогавашен околийски управител на Провадия ${ }^{8}$. Конкретните причини за уволнението на Тонев не са известни, но може да се предполага, че някой от министрите шуменци във Филовия кабинет е бил срещу оставането му на кметския пост.

Хараламбиев е от Трънско. Той е роден през 1906 г. Завършва държавни и правни науки в Софийския университет, след което известно време се занимава с адвокатство и журналистика в София. Член е на Демократическата партия до разпускането ѝ през 1934 г. Той е първи редактор на вестник „Студентска борба” - орган на Българския народен студентски съюз, което говори за по-левите му убеждения поне по онова време. Член е на дружеството на столичните журналисти. През 30-те години в продължение на 7 години е околийски управител на Шумен, което сочи ясно, че познава добре града и проблемите му (Haralanova, Rumenov 2002: 62).

С встъпването на поста Хараламбиев се опитва да интензифицира дейността на общината. Още на заседанието си на 12 март Общинският съвет по негово предложение взема решение да отстъпи едно общинско място от 30 декара и да отчужди някои частни парцели по пътя към с. Дибич, за да се построи там жп депо. Заедно с това общината взема принципното решение да започне да обработва земите си по кооперативен почин, като държавата в лицето на Министерството на земеделието и държавните имоти се ангажира да осигури необходимата техника. Общинската управа възприема и предложението на министерството да се построи винарска изба, като за целта купи фабрика „Ягода” със средства, отпуснати от БНБ9. За да се осигури необходимото количество обработваема земя за коопериране, Шуменската община създава и Комитет за подобряване и увеличаване на работната земя. Освен всичко друго кметьт има за цел да следи собствениците, които не обработват парцелите си или не ги дават под наем, и да им налага санкции

${ }^{8}$ Shumenski obshtinski vesti, № 10/ 18.03.1940, № 15/ 18.04.1940.

${ }^{9}$ Shumenski obshtinski vesti, № 10/ 18.03.1940. 


\section{Годишник на ФХH, XXXII A}

чрез глоби и дори отнемане на земята. По този начин обработваемата земя в Шумен се увеличава значително, което в условията на войната се отразява благоприятно за икономическото оцеляване и просперитет на региона.

Една от важните задачи на новото общинско ръководство е събирането на данъците. То е особено трудно по отношение на занаятчиите, защото наличието на стотици устни договорки между майстори, калфи, чираци и наемни временни работници затруднява изключително много следенето на приходите и разходите им. За да внесе някакъв ред, помощник-кметът Н. Шамарджиев публикува на 13. III. 1940 г. Заповед № 147, с която нарежда всички обущари, чехлари, сарачи, конфекционери, чантари и куфарджии от Шумен и околията да получат от комисарството при общината съответните формуляри и да декларират незабавно, в срок от 15 до 20 март, наличните си кожени материали, употребявани за производството, и тези, които са закупени от търговци от околията, но не са налични. Занаятчиите са предупредени в заповедта, че тези, които не се отзоват, ще бъдат санкционирани с глоби по чл. 10 от „Закона за облекчение /на/ продоволствието и намаление /на/ скъпотията“" като укриватели и нарушители на обществения ред. Направеното е и във връзка с „Наредба за единни типове и технически норми на кожените материали" на Министерството на търговията, промишлеността и труда, влязла в сила два дни по-рано ${ }^{10}$. Направеното повлиява значително върху живота на града, защото през посочения период обущарите и кожарите са най-много от всички занаятчии в околията - около 140 майстори с над 200 калфи, чираци и работници. Още през април е издадена и специална заповед за събиране на откупа за трудовата повинност от работодателите и самоосигуряващите се лица, който засяга всички мъже на възраст от 20 до 45 години, и внасянето му в общината. Взети са сериозни мерки и за почистването на Шумен, като са въведени забрани за произволното изхвърляне на битови отпадъци, трупове на домашни животни и птици, оборски тор, дървесна пепел, боклуци от нарязани дърва за огрев, отпадъчни води и пр. в реката и на обществени места ${ }^{11}$.

Една от добрите инициативи на Хр. Хараламбиев е акцията за построяване на нова сграда за Археологическия музей и Народната

\footnotetext{
${ }^{10}$ Darzhaven vestnik, № 56/ 11.03.1940. Заповедта на Шамарджиев вж. в Shumenski obshtinski vesti, № 10/ 18.03.1940.

${ }^{11}$ Shumenski obshtinski vesti, № 15/ 18.04.1940, № 71/ 27.05.1941.
} 


\section{Бисер Георгиев. Шумен по време на...}

библиотека в Шумен. През март 1940 г. се провежда специално събрание, на което присъстват областният директор Пенев, шуменският кмет, председателят на читалище „Арахангел Михаил” д-р Ал. Медникаров, председателят на Археологическото дружество „Българска старина” Ив. Моллов и др. Те вземат решение за София да замине делегация от трима души (Хараламбиев, Медникаров и Моллов), която, заедно с шуменските депутати Марин Тютюнджиев, Симеон Симеонов и Васил Велчев (от Първа новопазарска околия), да посети министьр-председателя проф. Б. Филов и да го помоли да съдейства за горепосочената цел. Филов изслушва делегацията с внимание и обещава още през следващия строителен сезон да изпрати в Шумен комисия, която да избере подходящо място за сградата и да изработи план за същата.

Делегацията използва времето на пребиваването си в столицата, за да посети и министьра инж. Д. Василев. Той ги уведомява, че на 1 и 17 април с. г. ще се проведат търговете в неговото министерство за избор на предприемач за павиране на участька от гарата до района на Пети артилерийски полк. Разширението на пътя с 5 метра ще бъде за сметка на Шуменската община. Като компенсация за това плановете за изграждане на канализация на Шумен са готови и от отпуснатия на общината заем в размер на 8, 5 млн. лв. от фонда „Общински налози”, 4 млн. ще бъдат изхарчени през тази година за канализацията.

Заедно с депутатите Тютюнджиев и Велчев, Хараламбиев посещава и Българската ипотекарна банка с цел да договори 12-милионен заем за строеж на ветеринарна служба и свинска кланица с цел експорт на свинско месо. Кметът има и други грандиозни планове, като например осъществяването на автобусна линия със или без заем ${ }^{12}$.

Инициатива за благоустрояването на града идва и от друга посока. През март Шумен е посетен от началника на Архитектурната служба при МОСПБ арх. Калчев и от арх. Л. Нейков от градоустройствената дирекция на столицата, които заедно със специалиста по градините и парковете Белов, заместник-кмета Шамарджиев и общинския лесничей Вълчев обикалят Шумен с цел да направят план за преврьщането на празните места в градски градини ${ }^{13}$.

12 Действително още през август с. г. е организирана Автобусна градска служба, финансирана със заем от Шуменската популярна банка в размер на 1, 75 млн. лв. Shumenski obshtinski vesti, № 30/ 06.08.1940.

${ }^{13}$ Shumenski obshtinski vesti, № 12/ 01.04.1940. 


\section{Годишник на ФХH, XXXII A}

С включването на двама министри шуменци в правителството на Б. Филов и промяната на кметското ръководство в града значението на Шумен се повишава. На 7. VII. 1940 г. градът е посетен от четирима министри едновременно, начело с министьр-председателя, което не се е случвало от времето на управлението на БЗНС. Заедно с главата на правителството пристигат финансовият министьр Д. Божилов и шуменците Багрянов и Василев. Високите гости пристигат в 9.00 часа сутринта с влак и още на гарата са приветствани от областния директор Ст. Пенев. След това се отправят към паметника на П. Волов, където са посрещнати от кмета, новия началник на гарнизона полк. Айрянов, граждани и строени войници и офицери. В желанието си да изпъкне пред премиера Хараламбиев заявява в приветствието си, че Шумен ,за първи път посреща" министьр-председател, което не е вярно и е откровен политически плонж към новата изпълнителна власт. Кметът се опитва да използва посещението, за да измоли от Багрянов помощ за постройката на екарисаж и за проектираната винарска изба, както и за назначаване на специалист агроном към общината и за изпращане на необходимата за кооперативното обработване на земята техника. Следват дежурните приветствия, след което министрите разглеждат водопроводната станция „Изгрев”, завода „Кабиюк” и старините в Плиска, Преслав и Патлейна. С това посещението приключва ${ }^{14}$, което подсказва, че не е посветено на конкретна цел, но въпреки това значението му за издигането на Шумен като важен политически и стопански център не е малко. Още същия месец Централният комитет за обществено подпомагане отпуска на Шуменската община 220000 лв. за подпомагане на ученическите трапезарии, детските летни игрища и ученическите лагери. Основната част от него (105 000 лв.) отива за трапезариите при женското благотворително дружество „Родолюбие”. Колонията „Висока поляна” и няколко летни детски игрища получават по 20000 лв., а други - между 5 и 10 хиляди. Между 2 и 3 хиляди получават и еврейското ${ }^{15}$, арменското и турското училище в града. От своя страна Шуменската община отпуска още 20000 лв. за посочените цели.

Направеното стимулира и инициативата на гражданите. Още на 3 август е учреден Кръжок на шуменската художествена колегия (Shepot v

\footnotetext{
${ }^{14}$ Shumenski obshtinski vesti, № 26/ 09.07.1940, № 27/ 13.07.1940.

15 Това са последните 2000 лв., които то получава преди гласуването на Закона за защита на нацията през ноември 1940 г., внесен от министъра на вътрешните работи П. Габровски. За последвалите събития вж. Kalcheva 2004.
} 
korenite 2004: 261), а малко след това е обявен търг за построяване на Пощенска палата в града на стойност 3, 2 млн. лв., която е готова само година по-късно ${ }^{16}$. На 20. Х. 1940 г. е основано и Кооперативно сдружение „Шуменски областен кооперативен санаториум” със седалище Шумен като продължение на основаната през юли 1939 г. Шуменска кооперативна болница ${ }^{17}$.

През юли 1940 г. екипът на „Шуменски общински вести” решава да проведе „Интервюта с областните шефове”. Журналистьт Петър Рибаров последователно интервюира директора Ст. Пенев, училищния инспектор Михайлов, областния лекар д-р Вербев, инж. Стойков, директора на Областната стопанска дирекция Ст. Попов, акцизния началник Ек. Бъчваров, полицейския началник Коранов и областния горски инспектор Михайлов. Всички те без изключение изказват мнението, че животът в Шуменска област тече спокойно, позитивно и постьпателно ${ }^{18}$.

На 7. IX. 1940 г. Румъния връща Южна Добруджа на България. Съгласно с подписаната Крайовска спогодба заселените в нея 88000 румънци са длъжни да я напуснат, а на тяхно място идват 68000 българи от Северна Добруджа (Kuzmanova 1989). Постигната е една голяма безкръвна победа, с която се възстановява историческата справедливост.

По подобие на целия български народ шуменци посрещат вестта за постигнатото възторжено. „Мирната победа е двойна победа” коментира общинският официоз ${ }^{19}$. Градът участва в присъединяването на областта и пряко. За въдворяването на реда и запазването на живота и имотите на българските граждани в Южна Добруджа е изпратен Седми пехотен Преславски полк. След завръщането си в Шумен той е посрещат тържествено от гражданите. Още през октомври в Шумен стартира кампания за подпомагане на бедните български ученици в Добруджа, събрала много средства и материали. Към това следва да прибавим, че от началото на ноември 1940 г. Южна Добруджа губи статута си на самостоятелна област, ръководена от специално изпратени там държавни чиновници и се прехвърля под юрисдикцията на Шуменска област, за

\footnotetext{
${ }^{16}$ Shumenski obshtinski vesti, № 85/ 28.10.1941.

${ }^{17}$ Shumenski obshtinski vesti, № 30/ 06.08.1940 (вж. и Shepot v korenite 2004: 261).

${ }^{18}$ Shumenski obshtinski vesti, № 27/ 13.07.1940.

${ }^{19}$ Интересен факт е, че той дава сведения за 100000 румънци, които трябва да напуснат, и само 35000 българи, които да се заселят. - Shumenski obshtinski vesti, № 37/ 24.09.1940.
} 


\section{Годишник на ФХH, XXXII A}

което Ст. Пенев издава специална заповед ${ }^{20}$. Така Шуменска област се увеличава извънредно много по размери и става една от трите най-големи по площ области в България.

След връщането на Южна Добруджа ревизионизмът се активизира. На 1. Х. 1940 г. първа страница на общинския вестник е посветена изцяло на Всебългарския съюз „Отец Паисий” и младежката му организация, които по-голямата част от съвременните автори считат за фашистки (Poppetrov 2008: 46-47; „Отец Паисий” е създаден през 1927 г., а младежката му организация - през 1931). От страниците на вестника председателят на Шуменския клон на организацията К. Танев призовава съгражданите си да станат членове на съюза, за да се ревизира и останалата част от Ньойския договор ${ }^{21}$. Подобна проява не може да бъде осъществена без съгласието на общинското ръководство, защото е малко вероятно първа и втора страница на вестника да са откупени от представителите на съюза. Това, от своя страна, говори за политическите възгледи на ръководителите на Шуменската община.

На 23. VIII. 1939 г. е подписан пактьт Молотов-Рибентроп, който развързва ръцете на Германия на запад (Dyukov 2009: 21 и сл.). Скоро обаче погледът на Хитлер се устремява и на изток. През ноември 1940 г. Унгария и Румъния се присъединяват към Тристранния пакт. С това натискът върху България се засилва (Sirkov 1972: 433-466). От своя страна СССР изпраща на 24 ноември като специален свой емисар Аркадий Соболев с предложение за сключване на договор за ненападение между Съветския съюз и България. То е отклонено, а официалната преса мълчи по случая, но благодарение на активната кампания на левите политически сили мисията на Соболев става широко известна (Chichikova 1972: 67 и сл.). Известна инициатива чрез акция за приемане на пакта, предложен от СССР на българското правителство, проявяват и шуменските леви сили (Shepot v korenite 2004: 259).

Активността на Хр. Хараламбиев през 1940 г. дава определени резултати, отчетени в края на с. г. на заседание на Общинския съвет на 4 декември. В обширния доклад са посочени и някои конкретни цифри за строителна дейност. Изхарчени са над 22 млн. лв., повечето от които са получени като заеми. Най-много средства са дадени за Инженерната палата (5, 5 млн.), Пощенската палата (5 млн. при пьрвоначално

\footnotetext{
${ }^{20}$ Shumenski obshtinski vesti, № 40/ 15.10.1940, № 43/ 05.11.1940 (вж. и Shepot v korenite 2004: 261).

${ }^{21}$ Shumenski obshtinski vesti, № 38/ 01.10.1940.
} 


\section{Бисер Георгиев. Шумен по време на...}

предвидени 3, 2), ремонта на банка „Български кредит” (2, 8 млн.), Финансовата палата (2 млн.), пристройката към Девическата гимназия (2 млн.), ремонта на църквата „Св. Възнесение” (1 млн.) и довършването на пансиона на Турското училище (1 млн.). Освен това са канализирани 19 улици с обща дължина на канализацията 4500 метра за 1, 87 млн. лв., получени по стопански начин. Поставени са бордюри на 28 улици и е положен 6200 кв. метра паваж, с което е извършено „цялостно павиране” на улиците в града. Прокарани са и над 21 км пьтища 22.

През януари 1941 г. мирният просперитет на шуменци е застрашен от неочакваното посещение на Б. Филов в немската столица (за преговорите там вж. Filov 1986: 200 и сл.). В следващия месец натискът на Берлин спрямо София за включване на България в Тристранния пакт е смазващ и въпреки някои лавирания на Борис III и правителството на 1 март 1941 г. България е присъединена. Часове по-късно германските войски преминават границата и влизат на българска територия (Toshkova 1964: 56-72).

Шумен посреща вестта за новия съюз с лека тревога, но без униние. „Мирьт е ценен, но победата е още по-ценна” - коментира ситуацията общинският официоз, възхищавайки се на германската военна мощ и дисциплина при преминаването на германските войници през града. Вестникът напомня, че това са старите български съюзници и изрично предупреждава гражданите да не обсъждат военни въпроси и да не вярват на „чужди слухове”. В един от следващите си броеве редакторите изказват и истинска радост от обстоятелството, че с помощта на Германия затегнатият около България обръч от неприятелски настроени държави „се скъса” 23 . Последното е ясен знак за пълно съгласие на общинската с централната държавна политика. Съвсем скоро е организиран и Общоградски комитет за събиране на подаръци за ранените германски войници в Македония и Тракия ${ }^{24}$.

Привидно и след присъединяването на България към силите на Оста животьт на шуменци продължава в едно сравнително благоприятно русло. През 1941 г. в града е основано Дружество на многодетните. През март с. г. е пуснато в експлоатация железопътното депо. Довършена е сградата на новата Пощенска палата. На 11 октомври министьр Д. Василев лично посещава Шумен, за да се увери, че благоустройствените

\footnotetext{
${ }^{22}$ Shumenski obshtinski vesti, № 49/17.12.1940.

${ }^{23}$ Shumenski obshtinski vesti, № 60/ 11.03.1941, № 63/ 01.04.1941.

${ }^{24}$ Shumenski obshtinski vesti, № 65/ 15.04.1941.
} 


\section{Годишник на ФХH, XXXII A}

работи в града вървят по план ${ }^{25}$. На 12 октомври новият земеделски министьр Д. Кушев (Иван Багрянов е изваден от правителството на 4 февруари 1941 г. - Balgarskite darzhavni institutsii 1986: 326) открива лично коневъдна изложба ${ }^{26}$, а на 27 с. м. е учредена трапезария за бедни ученици при Шуменската мъжка гимназия (Shepot v korenite 2004: 260). Вследствие на изключително щедрото дарение на ген. Рачо Петров от 500 хиляди лева (за живота и политическата дейност на генерала, който умира по-малко от година след това, на 22 януари 1942 г., вж. Kostov 2004) женското благотворително дружество „Родолюбие” е в състояние да започне и строеж на пансион за Девическата гимназия ${ }^{27}$. На 19 октомври (Shepot v korenite 2004: 260; авторите правят грешка, отнасяйки посоченото събитие на 27 октомври) е открита и железопътната линия Шумен - Карнобат. Това става с изключителна тържественост, при която с първия влак по линията, идващ от Карнобат, пътуват царят и царицата, председателят на Народното събрание Хр. Калфов, трима министри - Д. Божилов, инж. Д. Василев и Иван Горанов (министьр на железниците, пощите и телеграфите), главният директор на Българските железници Калчев, представители на германските власти, официални лица, столични журналисти и пр. ${ }^{28}$

Въпреки успехите в областта на стопанството и благоустройството, военновременната обстановка се усеща все по-силно. През април и май 1942 г. пресата обръща все по-голямо внимание на армията. Появяват се изрази от типа, че „само готовият да умре побеждава" 29 , което не е характерно за предходните години. Разбира се, това става поради обстоятелството, че на 20 април българската армия със съгласието на германското командване влиза в Беломорска Тракия под благовидната формулировка за запазване на „реда и спокойствието”. На 24 април е подписана спогодбата Клодиус - Попов. Нейни клаузи дават множество права на германците да разполагат с подземните богатства на Македония, без да решават окончателно българския национален въпрос. В отпечатаните през следващата година карти границите между България

\footnotetext{
${ }^{25}$ Shumensko slovo, № 225/ 18.10. 1941; Shumenski obshtinski vesti, № 83/ 14.10.1941. Вж. и Shepot v korenite 2004: 259-260.

${ }^{26}$ Shumensko slovo, № 225/ 18.10.1941. Речта на министъра Вж. в Shumenski obshtinski vesti, № 83/ 14.10.1941.

${ }^{27}$ Shumenski obshtinski vesti, № 65/ 15.04.1941.

${ }^{28}$ Shumenski obshtinski vesti, № 85/ 28.10.1941.

${ }^{29}$ Shumenski obshtinski vesti, № 68/ 07.05.1942.
} 


\section{Бисер Георгиев. Шумен по време на...}

и Сърбия и България и Гърция (от 27 април спогодбата влиза в сила и за нея) са представени само като демаркационна линия. Това, разбира се, не пречи на Борис III и българското правителство да представят пред общественото мнение случилото се като завършване на националното обединение, за което дори е изработена специална карта (Istoria na Bulgaria 2012: 386-387; картата вж. на с. 388). За пореден път Кобургите си играят с нараненото национално чувство на българския народ.

На 27 август по инициатива на Министерството на народната просвета в Шумен са поканени на „опреснителен курс” български учители от Македония, посрещнати с голяма тържественост ${ }^{30}$.

След нападението на Германия над Съветския съюз на 22. VI. 1941 г. политическата обстановка в Европа се променя и обществото все повече се поляризира. Това води до втвърдяване на тона на политическата преса. През есента на 1941 г. „Шуменски общински вестник” вече си позволява да нарече „болшевиките” „професионални безотечественици” и да определи „дългът на българина” като запазване с оръжие на земята „от Охрид до Черно море” и „от Дунав до Бяло море”31. Подобен агресивен тон се появява за първи път от началото на Втората световна война и няма да е последен.

На 27. XI. 1941 г. в Шумен се провежда голяма манифестация на учащата се младеж по повод рухването на Ньойския договор. Тя завършва с тържествено събрание, на което държи реч кметьт Хр. Хараламбиев $^{32}$. Десет дни по-късно британските доминиони Канада, Австралия и Нова Зеландия обявяват война на всички държави от Оста, включително България. Поводът е нападението на Япония над Пърл Харбър. На 12 декември под натиска на германската дипломация Министерският съвет взема решение за обявяване на война на Великобритания и САЩ. Борис III го одобрява още същия ден, а на 13 декември го гласува и Двадесет и петото народно събрание (Istoria na Bulgaria 2012: 390-391 и цит. лит). Така София се заплита в сериозни усложнения с тежки последици. „Символичната” война скоро става съвсем реална с бомбардировките на английски и американски изтребители над столицата и десетки български градове (Kalinova 2004: 131 и сл.).

\footnotetext{
${ }^{30}$ Shumenski obshtinski vesti, № 77/ 02.09.1941.

${ }^{31}$ Shumenski obshtinski vesti, № 83/ 14.10.1941.

${ }^{32}$ Shumenski obshtinski vesti, № 90/ 02.12.1941.
} 


\section{Годишник на ФХH, XXXII A}

1942 г. започва за Шумен с опит за установяване на пълен контрол върху печата. Независимите вестници в града и без това вече почти не съществуват. „Шуменска заря” спира да излиза още през 1940 г., а „Шуменски глас” - през $1941^{33}$. „Шуменско слово” продължава да излиза всяка събота в тираж около 2000 броя, но поради цензурата все по-слабо отразява политическите събития ${ }^{34}$. Въпреки това Дирекцията на националната пропаганда свиква на 11 и 12. I. 1942 г. във Варна конференция, на която началникът на отделението по печата Кр. Далчълъчев обяснява на вестникарите, че ролята на провинциалния печат е „мисионерска” - да служи на интересите на държавата. От Шумен присъстват само представители на „Шуменски общински вести” и сп. „Земеделска камара” - печатен орган на Шуменската земеделскостопанска камара, разпространяван безплатно в тираж около 2400 броя ${ }^{35}$.

Въпреки войната благоустройството на Шумен продължава с високи темпове, заслуга за което има най-вече инж. Д. Василев. Министърьт прави всичко възможно родният му град и през 1942 г. да получи сериозно количество средства за нови строежи и благоустройство в размер на 10 млн. лв. Пет от тях са определени за довършване на Девическата гимназия, строежът на която приключва още през юни 1942 $\Gamma^{36}$ Три са за започване на сградата на Археологическия музей и Народна библиотека и два за довършване на сградата на Учителския институт. Увеличен е и годишният бюджет на Шуменската община на 18, 855 млн. лв. (сумата е закръглена до 1000 лв. - б. а. Б. Г.) и то при условие, че бюджетьт за 1941 г. е изпълнен едва на $90 \%{ }^{37}$. Така, поради наличието на стабилно лоби във властта, Шумен за първи път в новата българска история се преврьща в „галеното дете” на държавата.

Войната и постигнатите от правителството „успехи” за обединението на нацията стимулират изявите на крайно десните организации. На 1. III. 1942 г., по повод присъединяването на България към Тристранния пакт, шуменския клон на „Бранник”, ръководен от Станчев, провежда манифестация по града, завършила с митинг и патриотични речи пред паметните плочи на загиналите от Седми

\footnotetext{
${ }^{33}$ Shumenska zarya, № 130/ 25.02.1940; Shumenski glas, № 1124/ 1941.

${ }^{34}$ Вж. напр. Shumensko slovo, № 262/ 11.07.1942, № 263/ 18.07.1942.

${ }^{35}$ Shumenski obshtinski vesti, № 96/ 13.01.1942.

${ }^{36}$ Shumenski obshtinski vesti, № 116/ 23.07.1942.

37 Shumenski obshtinski vesti, № 100/ 17.02.1942. Конкретните предвидени строителни мероприятия са отразени до най-малки подробности.
} 


\section{Бисер Георгиев. Шумен по време на...}

Преславски пехотен полк ${ }^{38}$. Ефектьт от него е толкова голям, че поне в пресата засенчва честването на 3 март.

На 12. IV. 1942 г. проф. Б. Филов трансформира кабинета си, поемайки Министерството на външните работи вместо Ив. Попов. Направени са и други промени, но Д. Василев запазва поста си (Istoria na Bulgaria 2012: 422; Balgarskite darzhavni institutsii 1986: 327).

Шуменци посрещат промяната на Филовия кабинет с пълно одобрение на действията на министьр-председателя. Общинският вестник публикува речта му към нацията от 13 април с възторжен коментар. Като благодарност Шумен получава възможност да придобие нова железопътна линия Шумен - Хитрино, проектът за която е стартиран веднага ${ }^{39}$. Малко по-късно е открито Акушеро-гинекологично отделение на Шуменската първостепенна болница (Shepot v korenite 2004: 261). През с. г. Общинският съвет взема решение за сключване на заем от 12 млн. лв. от БЗК за млечна централа, кланица и разширяване на съществуващите кланици. В центъра е открита Данъчна палата в присъствието на министрите Д. Божилов и инж. Д. Василев - това е единствената постройка от този тип с душове за служителите. Завършено е водоснабдяването на града с включването на помпените станции „Баш бунар” и „Струма”, които осигуряват 34 литра вода за пиене за секунда. Така градът е водоснабден. Извършва се канализация, като за 4 години са канализирани 39 улици с обща дължина 6990 м, а общо са канализирани 50 улици с дължина на каналите 10600 м. Благоустройството включва и създадената нова градина при пл. „Оборище”, градината пред Съдебна палата, градската градина с нов портал от 6 колони, с асфалтирани алеи и създаденото там „Чилингирово кътче”, в което писателят засажда бреза. На 28 юни е открита официално първата шуменска омнибусна линия. За първи път се въвежда званието „Почетен гражданин на Шумен”, като през 1942 г. за такива са провъзгласени: бившият министьр д-р К. Миланов, министьрът на благоустройството инж. Д. Василев ${ }^{40}$, писателят Ст. Чилингиров и шуменският областен управител Ст. Пенев ${ }^{41}$.

\footnotetext{
${ }^{38}$ Shumenski obshtinski vesti, № 102/ 03.03.1942.

${ }^{39}$ Shumenski obshtinski vesti, № 108/ 21.04.1942.

40 Запазено е писмото, с което на 16 септември 1943 г. инж. Димитър Василев е уведомен, че е обявен за почетен гражданин на Шумен заради многобройните му заслуги към този град. ТДДА - Шумен, ф. 34к, оп. 1, а. е. 123, л. 115. Писмо на шуменския кмет Хр. Хараламбиев до инж. Д. Василев.

${ }^{41}$ Shumenski obshtinski vesti, № 112/ 26.05. 1942, № 117/ 30.06.1942.
} 


\section{Годишник на ФХH, XXXII A}

На 25. Х. 1942 г. в читалище „Архангел Михаил” в Шумен се провежда областна конференция на околийските управители, кметовете и помощник-кметовете на Шуменска област. На нея Ст. Пенев произнася двучасова „политическа реч”, в която очертава идейните насоки на настоящия „безпартиен режим” (двете понятия са оксиморон - б. а., Б. Г.). Безсмислената в общи линии реч е отпечатана в самостоятелна брошура ${ }^{42}$.

Както отбелязахме по-горе, развитието на войната засилва позициите на крайно десните сили. Скоро в Шумен се създава подразделение в „Бранник” и на девойки под командването на П. Георгиева. Влиянието им в Шумен явно е дотолкова силно, че директорьт на Девическата гимназия В. Хлебаров поздравява подразделението ${ }^{43}$.

Историческата победа на съветските войски над хитлеристите при Сталинград на 2. II. 1943 г. преобръща хода на Втората световна война. След пълния разгром на Шеста германска армия става ясно, че немските войски на Източния фронт минават в отстъпление. Част от българските дипломати препоръчват „по-гъвкава политика” с цел постепенно излизане от Оста (Istoria na Bulgaria 2012: 396-396 и цит. лит).

В Шумен обстановката става по-тревожна, но старата политика се запазва. В началото на април 1943 г. градът е посетен от унгарския министьр Д. Арноти по повод откриването на паметник на Лайош Кошут. Успоредно с това кметьт Хараламбиев почва да работи по сключването на нов заем от 10 млн. лв. за построяване на нова модерна баня „с плавателен басейн”. Около два месеца по-късно, на 30 май, министрите Д. Божилов и Д. Василев, пристигнали за откриването на новопостроената Данъчна палата, правят кратка обиколка из Шуменския край ${ }^{44}$.

Едно от запомнящите се постижения на Христо Хараламбиев е провеждането на процедура за изработване на герб на Шуменската община. Той е създаден от художника Н. Бояджиев, излят от скулптора Павел Метеоров и поставен на фасадата на Шуменския Общински дом през юни 1943 г. Малко по-късно кметът започва кампания за събиране на материали за попълване на летописна книга на града (Haralanova, Rumenov 2002: 64).

\footnotetext{
${ }^{42}$ Shumenski obshtinski vesti, № 127/ 03.11.1942.

${ }^{43}$ Shumenski obshtinski vesti, № 131/ 08.12.1942.

44 Shumenski obshtinski vesti, № 146/ 06.04.1943, № 154/ 04.06.1943; вж. и Shepot v korenite. 2004: 259, 261.
} 


\section{Бисер Георгиев. Шумен по време на...}

Въпреки успехите местната власт е леко притеснена и това започва да се усеща по приповдигнатия тон. На 1 май общината се опитва да организира масови казионни тържества за работниците ${ }^{45}$, за да ги отклони от протестните движения. Известни основания за това съществуват, защото през април 1943 г. нелегалната комунистическа съпротива учредява Девета въстаническа оперативна зона с центьр Шумен. До сформирането на партизанския отряд „Август Попов“ на 22. X. 1943 г. (Shepot v korenite 2004: 261) тя е само на книга, но секретните сведения за същото вероятно изпълват с известен страх живота на властите.

От своя страна, за да подкрепи управляващите, общинската преса се пълни с материали за големите успехи на шуменското село вследствие кооперирането на земята. Говори се за тригодишни планове, дават се първенци за пример (село Дибич) и пр. Заедно с това не се пише нищо за Източния фронт, а информациите, които се поместват, са за Далечния изток, където японците предприемат настьпление срещу англичаните.

Колкото и да се стремят да скрият от хората истината (в брой 161 на „Шуменски общински вести” кметът Христо Хараламбиев излиза със специална статия под заглавие „Шумен безшумно твори”, в която описва постиженията на общината в областта на строителството и благоустройството), властите не успяват да прикрият някои очевидни неуспехи. Въпреки огромните средства, налети от държавата в града, в средата на 1943 г. съществуват сериозни икономически проблеми, включително с изхранването на населението. През юни с. г. общината за първи път от началото на войната е принудена да оповести публично чрез пресата пунктовете за раздаване на купони за хляб, определени в десет различни училища. Въведени са и строги ограничения. Градът е райониран по улици. Картите се раздават само до 30 юни и то единствено в специално определените за това места. Купоните за допълнителен хляб и други привилегии се дават директно в комисариата при общината, а на гражданите се забранява да получават „безразборно” съответните книжки от останалите секции. Извършени са и някои съкращения и премествания в полицейския апарат. Полицейският комендант на Шумен Георги Ст. Алексиев е преместен на работа в Сливен, а груповият началник Матей Ал. Матеев - в столицата. За да се ськратят средства, са

\footnotetext{
45 Такива се провеждат в Пивоварната фабрика, фабриката на Павел Байнов, Картела, фабрика „Слънце”, фабриката на Георги Карамфилов и Марин Христов и печатницата на Спас Попов (Shumenski obshtinski vesti, № 150/ 04.05.1943).
} 


\section{Годишник на ФХH, XXXII A}

уволнени фотографът в полицията, машинописката и адресната чиновничка. Всичко това е оповестено в пресата ${ }^{46}$ без присъщия в подобни предходни случаи коментар. Към това следва да прибавим, че точно през лятото и есента на 1943 г. печатният орган на общината започва да излиза с огромни прекъсвания явно поради липсата на финансови средства.

На 25. VII. 1943 г. в Рим е извършен безкръвен преврат, който събаря Мусолини от власт (Dimitrov 1976: 247 и сл.). Няколко седмици по-късно Борис III отива на среща с Хитлер в Берлин, след завръщането на която умира на 28 август при неизяснени обстоятелства според медицинската диагноза. В следващите две седмици опозицията подема инициатива за свикване на Велико народно събрание за избор на регенти, но дейността ѝ е анемична (Todorov 2018: 473-474 и цит. лит.) и не постига успех. На 9 септември Двадесет и петото обикновено народно събрание, в нарушение на Конституцията, избира за регенти Кирил Кобурготски, Б. Филов и ген. Н. Михов. На 14 септември е съставено ново правителство начело с бившия финансов министьр Добри Божилов. Шуменският министьр инж. Димитър Василев остава в него, запазвайки поста си (Balgarskite darzhavni institutsii 1986: 327), но ситуацията постепенно става критична и, продължавайки да се държи заедно с Хитлеристка Германия (Toshkova 1974: 3-34), България тръгва към поредната национална катастрофа.

В посочения период Шумен става ням свидетел на събитията, без да може да се намеси. Поддържайки до последно централната власт, в своя отчет пред Общинския съвет за изминалата 1943 г. кметът представя финансовото състояние на общината като блестящо, а предстоящите перспективи - като отлични ${ }^{47}$, но вече на всички е ясно, че дейността върви по инерция и по нанадолнището.

На 13. II. 1944 г. в Шумен се провежда едно от последните големи публични събрания на авторитарната власт, основната реч на което произнася депутатьт Марин Тютюнджиев. В нея той описва глобалната война повече като „стопанска”. За пореден път се опитва да играе на тънката струна - опазването на „Обединена България”, но на фона на опустошителните бомбардировки на столицата и други градове, срещу

\footnotetext{
${ }^{46}$ Shumenski obshtinski vesti, № 156/ 14.06.1943, № 161/ 13.10.1943.

${ }^{47}$ Shumenski obshtinski vesti, № 171/ 22.01.1944.
} 


\section{Бисер Георгиев. Шумен по време на...}

които шуменци с основание протестират ${ }^{48}$, думите му звучат като евтина пропаганда.

На 12. II. 1944 г. Хр. Хараламбиев, назначен с указ на Регентския съвет, поема длъжността директор на Шуменска област. Това е престижно издигане в кариерата лично за него, но в близко бъдеще става сериозна причина за най-тежката присъда, произнесена от Народния съд (осъден е на смърт на 30. XI. 1945 г. - Haralanova, Rumenov 2002: 72).

Последният кмет на Шумен до идването на Отечествения фронт на власт е роденият през 1910 г. в града Иван Б. Попов. Същият е бледо копие на баща си Борис Попов (бивш кмет, завършил право в Лозана, дългогодишен лидер на Демократическата партия в Шумен). Той също завършва право, но в Софийския университет. Заема кметското място от 27 април до 11 септември 1944 г. До заемането на поста Попов работи като адвокат в Шумен. Според някои автори стои на социалистически позиции, но същевременно, съвместно с В. Радушев и Панко Симеонов, е основен акционер в тютюневата фабрика „Преслава”. Едновременно с това е редактор на вестник „Шуменско слово” в периода юли 1942 февруари 1944 г. ${ }^{49}$ Поради войната, а вероятно и по други причини, дейността на Ив. Попов като кмет е анемична, свързана главно с изхранването на населението. Единствената по-сериозна инициатива, която предприема, е създаването на професионален Шуменски общински театър, учреден на 19. VII. 1944 г. Друго негово постижение е, че допринася за мирното предаване на общинската власт от Отечествения фронт на 11. IX. 1944 г. (Haralanova, Rumenov 2002: 68).

Въпреки грижите, които авторитарната власт полага за Шумен, жителите на града са обикновени хора и посрещат с овации и цветя преминаващите съветски войски. Към това следва да прибавим, че на 21. IX. 1944 г. легендарният Седми пехотен Преславски полк, изнесъл на плещите си не едно сражение в пет войни, заминава за фронта, за да вземе участие в Първата фаза на „Отечествената война”,

\footnotetext{
${ }^{48}$ Shumenski obshtinski vesti, № $175 / 22.02 .1944$.

${ }^{49}$ Shumensko slovo, № 263/ 18.071942. Последен брой на вестника е № 340/ 12.02.1944.

${ }^{50}$ На 9 септември 1944 г. отечественофронтовското правителство, дошло на власт с преврат, обявява война на Германия, за да избегне националната катастрофа. За целта е сформирана и Първа българска армия, в състава на която влиза Седми Преславски полк. Страната обаче още от 1941 г. е във война със САЩ, Великобритания и доминионите иे, а на 5 септември 1944 г. СССР обявява официално война на България. Така се създава абсурдната недостигната до този момент от никого външнополитическа ситуация една малка държава да бъде във война с всички велики сили едновременно.
} 


\section{Годишник на ФХH, XXXII A}

изпратен на гарата от шуменското гражданство (Shepot v korenite 2004: 261).

\section{ИЗПОЛЗВАНА ЛИТЕРАТУРА}

Balgarskite darzhavni institutsii 1986: Balgarskite darzhavni institutsii 1879-1886. Entsiklopedichen spravochnik (sast. Metodiev, V., L. Stoyanov). Sofia: D-r Petar Beron [Българските държавни институции 1879 - 1886. Енциклопедичен справочник (съст. Методиев, В., Л. Стоянов). София: Д-р Петър Берон].

Chichikova 1972: Chichikova, V. Sobolevata aktsia (istoricheski ocherk). Sofia [Чичикова, В. Соболевата акция (исторически очерк). София].

Dimitrov 1969: Dimitrov, I. Burzhoaznata opozitsia v Bulgaria 1939-1944. Sofia: Nauka i izkustvo [Димитров, И. Буржоазната опозиция в България 19391944. София: Наука и изкуство].

Dimitrov 1976: Dimitrov, I. Balgaro-italianski politicheski otnoshenia (1922-1943). Sofia: Nauka i izkustvo [Димитров, И. Българо-италиански политически отношения (1922-1943). София: Наука и изкуство].

Dyukov 2009: Dyukov, A. „Pakt Molotova - Ribbentropa” v voprosah i otvetah. Moskva: Fond „Istoricheskaya pamyaty” [Дюков, А. Р. „Пакт Молотова Риббентропа“ в вопросах и ответах. Москва: Фонд „Историческия память"].

Filov 1986: Filov, B. Dnevnik. Sofia: Otechestven front [Филов, Б. Дневник. София: Отечествен фронт].

Haralanova, Rumenov 2002: Haralanova, B., D. Rumenov. Almanah na shumenskite kmetove 1878-2002. Shumen [Хараланова, Б., Д. Руменов. Алманах на шуменските кметове 1878-2002. Шумен].

Ignatovski 2005: Ignatovski, D. Deputati ot Shumenskia kray 1879-2005. Shumen: Aksios [Игнатовски, Д. Депутати от Шуменския край 1879-2005. Шумен: Аксиос].

Istoria na Bulgaria 2012: Istoria na Bulgaria. T. 9. Sofia: BAN [История на България. Т. 9. София: БАН].

Kalcheva 2004: Kalcheva, D. Holokostat na Balkanite. Sofia [Калчева, Д. Холокостът на Балканите. София].

Kalinova 2004: Kalinova, E. Pobeditelite i Bulgaria (1939-1945). Sofia: UI „Sv. Kliment Ohridski” [Калинова, Е. Победителите и България (1939-1945). София: УИ „Св. Климент Охридски“"].

Kostov 2004: Kostov, E. Racho Petrov - ofitserat, politikat, darzhavnikat. Sofia: UI „Sv. Kliment Ohridski” [Костов, Е. Рачо Петров - офицерът, политикът, държавникът. София: УИ „Св. Климент Охридски“].

Kuzmanova 1989: Kuzmanova, A. Ot Nyoy do Krayova. Vaprosat za Yuzhna Dobrudzha v mezhdunarodnite otnoshenia (1919-1940). Sofia: Nauka i izkustvo [Кузманова, А. От Ньой до Крайова. Въпросът за Южна 
Добруджа в международните отношения (1919-1940). София: Наука и изкуство].

Poppetrov 2008: Poppetrov, N. Fashizmat v Bulgaria. Razvitie i proyavi. Sofia: Kama [Поппетров, Н. Фашизмът в България. Развитие и прояви. София: Кама].

Sirkov 1972: Sirkov, D. Kam vaprosa za prisaedinyavaneto na Bulgaria kam Tristrannia pakt. - Balgaro-germanski otnoshenia i vrazki. Sofia: BAN [Ширков, Д. Към въпроса за присъединяването на България към Тристранния пакт. - Българо-германски отношения и връзки. София: БАН].

Shepot v korenite 2004: Shepot v korenite. Kniga za staria Shumen (sast. Nedev, N., N. Popov, Sl. Nikolov). Shumen: Slavcho Nikolov i sie [Шепот в корените. Книга за стария Шумен (съст. Недев, Н., Н. Попов, Сл. Николов). Шумен: Славчо Николов и сие].

Todorov 2018: Todorov, T. St. Nikola Mushanov - zhivot i obshtestvena deynost. Veliko Tarnovo: Ivis [Тодоров, Т. Ст. Никола Мушанов - живот и обществена дейност. Велико Търново: Ивис].

Toshkova 1964: Toshkova, V. Prisaedinyavaneto na Bulgaria kam Tristrannia pakt. // Istoricheski pregled, 1964, № 4, s. 56-72 [Тошкова, В. Присъединяването на България към Тристранния пакт. // Исторически преглед, 1964, № 4, c. 56-72].

Toshkova 1974: Toshkova, V. Vanshnata politika na pravitelstvoto na Dobri Bozhilov (septemvri 1943 - may 1944 g.). // Istoricheski pregled, 1974, № 2, s. 3-34 [Тошкова, В. Външната политика на правителството на Добри Божилов (септември 1943 - май 1944 г.). // Исторически преглед, 1974, № 2, с. 3-34].

\section{ИЗПОЛЗВАНИ ИЗТОЧНИЦИ И ПЕРИОДИЧНИ ИЗДАНИЯ}

Darzhaven vestnik 1940 - „Дьржавен вестник“

Shumenski glas 1939-1941 - в. „Шуменски глас“

Shumenski obshtinski vesti 1940-1944 - в. „Шуменски общински вести“

Shumensko slovo. 1941-1942, 1944 - в. „Шуменско слово“

Shumenska zarya 1939-1940 - в. „Шуменска заря“

TDDA - Териториална дирекция на Дьржавен архив, Шумен 